\title{
The Implementation of Qauniyah Verses Based on Unification Curriculum in SMA Trensains
}

\author{
Rahmat Ryadhush Shalihin ${ }^{*}$, Fitrohtin Bahriya*2, Wantini*3 \\ 1,2,3 Universitas Ahmad Dahlan, Yogyakarta
}

e-mail: ${ }^{1}$ rahmatshalihin@yahoo.co.id, ${ }^{2}$ fitrohtin94gmail.com, ${ }^{3}$ wantini@mpai.uad.ac.id

\begin{abstract}
The curriculum in Indonesia has been changed eleven times since 1947th. In fact, the changes that are expected to increase education globally and nationality especially in Islamic Education, have not already revolutionary era yet. As one of independently formal Islamic Education, SMA Trensains Muhammadiyah, Sragen made their own curriculum named "unification curriculum". It has a lot of programs implemented in each variety schedule, particularly in Islamic Education. Those unique activities combine not only in theoretical things and classical methods, but also directly applicated the qauniyah verses in the Quran through the technology and learning media. The aims of this paper are to describe how the curriculum in Trensains worked and implemented the verses Quran in different ways from the others. This research uses field research with qualitative methods. Then the data analyze with descriptive ways. The results of this study showed that through the implementation of the unification curriculum in Trensains learning process between Islamic education and natural science collaborated increasing of intellectual and spiritual of students. The students more interactive and productive in integrative curriculum with qauniyah verses in Qur'an and science rather than conventional process.
\end{abstract}

Keywords. Unification Curriculum; Islamic Education; Learning Media

Abstrak. Kurikulum di Indonesia telah mengalami perubahan sebanyak sebelas kali semenjak tahun 1947. Realitasnya, perubahan yang diharapkan untuk meningkatkan pendidikan secara global dan nasional khususnya di Pendidikan Islam, belum mencapai tahap revolusioner. Sebagai salah satu lembaga Pendidikan Islam independen, SMA Trensains Muhammadiyah telah menciptakan kurikulum mandiri yang disebut "Kurikulum Unifikasi". Kurikulum tersebut memiliki berbagai program yang diimplementasikan secara terjadwal, khususnya dalam Pendidikan Islam. Kegiatan ini tidak hanya bersifat teoretikal dan klasikal, akan tetapi langsung mengaplikasikan ayatayat kauniyah dalam Al-Qur'an melalui media pembelajaran dan teknologi. Tujuan penulisan dalam penelitian ini adalah menjelaskan cara kerja kurikulum di Trensains dan implementasi ayat-ayat Al-Qur'an melalui metode yang berbeda. Penelitian ini menggunakan studi lapangan dengan metode kualitatif. Analisis data menggunakan deskriptif kualitatif. Hasil penelitian menunjukkan melalui implementasi kurikulum unifikasi di SMA Trensains dalam proses pembelajaran antara Pendidikan Islam dan natural sains dapat meningkatkan pemahaman intelektual sekaligus spiritual siswa., Siswa menjadi lebih interaktif dan produktif melalui kurikulum integratif antara ayatayat qauniyah Al-Qur'an dengan sains daripada pembelajaran konvensional.

Kata Kunci. Kurikulum Unifikasi; Pendidikan Islami; Media Pembelajaran.

Copyright (C JMPI: Jurnal Manajemen Pendidikan Islam. All Right Reserved.

This is an open access article under the CC BY-NC-ND license

(http://creativecommons.org/licenses/by-nc-nd/4.0/).

Vol. 4 No. 2, Desember 2019

J-MPI homepage: http://ejournal.uin-malang.ac.id/index.php/jmpi/index 


\section{A. INTRODUCTION}

Curriculum as the design of entire activities provided to achieve education purposes has a central function, at least in personality enrichment. The old concept curriculum as content, purposes, instructional planning, and document $(\mathrm{Su}, 2012)$. is no longer in this era. During this time, Islamic Education more emphasizes in 'knowing' and 'doing' aspects, rather than 'being' side that teaches students how to applicate of 'knowing' (Nurmadiah, 2014). Islamic education also defense itself onto technology and information development (Priatmoko, 2018). In this 4.0 era, Islamic Education has to change in progressivity and modernity forms. As the core of Islamic Education, according to Al-Syaibani said the curriculum reflected of the Islam's spirit which is universal through all of the living human aspects, intellectual, social, psychological, and spiritual (Silahudin, 2014). Besides, the development of Islamic curriculum also mention in KMA No. 11, 2011 about Pedoman Pengembangan Standar Nasional Pendidikan Agama Islam di Sekolah (Guidelines for the Development of National Standards of Islamic Education in School) and one of the development program is Islamic education based on science integration (Kementerian Agama RI, 2019).

Furthermore, according to Pew Research Center data that Indonesia is the largest population Muslims up to $87,2 \%$ (Hackett, 2012) with a high religious mindset as much as $99 \%$ with the 4 th in the world (Crabtree, 2010). Thus data indicate that Islamic education in Indonesia has quantity increase but also lower perform in quality (Stoet \& Geary, 2017). So that, curriculum of Islamic education, particularly in Indonesia have to improve and develop in practical and empirical ways. In fact, the curriculum of Islamic Education in reality of majority formal school always depends on national execution without the development of new system that can bring to implementation and innovation between Islam and science. Generally, the learning process in school about natural science did not directly correlate to spiritual perspective or in this case named rububiyah's tauhid (Hermawan, 2017). Also, neither spiritual aspect in Islamic curriculum discussed in natural and empirical perspective.

Based on this problem, SMA Trensains Muhammadiyah in Sragen as one of independently Islamic school in Indonesia made their own curriculum and combined three aspects, starts from knowing, doing, and being. The curriculum in this high school named "Unification Curriculum" as known as integration curriculum represent big ideas of Trensains that combine science and Islam which is means science-based on Qur'an perspective, especially in qauniyah verses. This philosophy and matter of this curriculum are collaborates between Quran matter, science matter, and linguistic matter. Technically, the "Unification Curriculum" is an adaptive curriculum that collaborate national curriculum and their own Trensains curriculum. In 24 hours, this integrates curriculum works in daily activity of Trensains's student life. As Fazlur Rahman as a person who is neo-modernism (Ajahari, 2016) said that through the integrative of Islamic Education will empower of standardization, especially Islamic Education. Trensains one step ahead than general Islamic Education in Indonesia, between religious activity by practice, more than 800 qauniyah verses in Quran (Harahap, 2018) based on science projectivity through observation and experimentation of natural phenomena with scientific method (Yusuf \& Sutrisno, 2017).

Consequently, this paper analyzes activities in SMA Trensains Muhammadiyah, particularly the implementation of qauniyah verses in Quran. Each one of these programs

Vol. 4 No. 2, Desember 2019

J-MPI homepage: http://ejournal.uin-malang.ac.id/index.php/jmpi/index 
applicates the qauniyah verses through technologies media while teacher as a mentor and guide of students. These activity divided based on support program named The Science Deepening Program, that are research activity and observation, midnight program, and studium general. These various activities are support program in Trensains's curriculum thus become progressive and role model for Islamic High School in this era.

\section{B. METHOD}

This research uses the qualitative method which is more concerned about the formation of substantive theories based on empirical data in field study (Hasanah, 2018). In this research, data is gathered from library literature and observation in support programs of students in SMA Trensains. The researcher analyzes literature data and field data by Miles and Huberman's theory focusing on data reduction, presentation, conclusion, and data verification (Miles, Huberman, \& Saldaña, 2014).

\section{RESULTS AND DISCUSSION}

Pesantren is the indigenous Islamic education in Indonesia in order to transmit product of thought traditional Islamic scholasticism. In middle age, Islamic education had been tremendous progression in dualism ways, conservatism and rationalism. Conservatism completely indirectly impacted of model and implementation of Islamic education (Yusuf, 2015) towards to splitted thinking of style or dichotomy. Indonesia as the biggest majority muslims country (Pew Research Center, 2012) also faces dualism perspective (Muslih, 2018). Because the large population Moslems in Indonesia, Islamic education could it be required to do the transformation in retrospective and prospective area that preparation oriented for the future according to Mochtar Buchori (Mustakim, 2017). The issue brings the reformation and reconstruction in Islamic education into integration or rapprochement (Yusuf, 2015), especially in formal education. Rapprochement and integrated curriculum as a new model curriculum is the integration of skills, themes, concepts, and topics in interdisciplinary and multidisciplinary science (Kurroti A'yun, Wildanul Fajri, 2018). Unlikely the general schools, thus programs also have to consider contextual and cultural in Indonesia (Muttaqin, 2018).

One of the role model of the integration comes from Trensains with the modernization of educational system between school and pesantren into one system of education (Maksudin, 2018). Trensains or Pesantren Sains (Science Boarding School) initiated by Agus Purwanto (Muttaqin, 2018) which is synthesis between boarding school and natural science school. Trensains also combines salaf, modern, and independent school, all three typologies simultaneously with the superiority by making Quran and Hadith as the basis for the development of natural science. So, students are qualified in science and religion, strongly holds the Qur'an and Hadith, developing science, and philosophical depth can be produced (Munadi, 2016). In specifically, Trensains bring the understanding of Qur'an and Hadith, also natural science through interacted both of sides. This interacted through technologies and media in the learning process (reported on Sunday, October 13, 2019 at 01.30 PM) did not belong to other boarding school and only made in Trensains that are divided into below of this programs:

Vol. 4 No. 2, Desember 2019

J-MPI homepage: http://ejournal.uin-malang.ac.id/index.php/jmpi/index 
1. Research activity and observation

First, the program in "Unification Curriculum' that implemented of qauniyah verses in Quran is research activity and observation. This program divided into two part, laboratory of universe verses (Ayat-ayat Semesta/AAS) and Science Project. Both programs are implemented outside of primary learning process classroom. In Islamic science, AAS not only interacted with one side, but also construct the science and technology based on paradigm basis in Quran. The aims of this program is built of students capability in both side, between intellectual and spiritual as a creature of God (Khoirudin, 2017). Meanwhile, the laboratory of AAS established in 2014 as the core of Trensains. According to Agus Purwanto as the founding father of Trensains, said this laboratory became a primary activity in natural science, not social science, such as biology, physic, and chemistry like what reported by umm.ac.id on November 10, 2018. Observation in AAS guided by an expert domestically and globally to provide students in Quran, science, and linguistic (Muslih, 2018). The project of AAS not only combines between Qur'an and science, but moreover required science from understanding qauniyah verses in Qur'an and instruments of natural science that inspired directly from Quran (structure, vocabulary, and all of Qur'an dimension) (Khoirudin, 2017). In Quran there are more than 800 qauniyah verses that provide to guidance human in discussed about natural phenomenon (Harahap, 2018), for examples electrical (Q.S An-Nur: 35), atmosphere (Q.S Fushilat:12), energy (Q.S Yasin: 80, Q.S Waqi'ah: 71-73, Q.S Thaha: 10, Q.S An-Naml: 7), measurement (Q.S Al-An'am: 152, Q.S Al-A'raf: 85), soundwave (Q.S Al-Kahfi: 26, Q.S Saba' 50), colour (Q.S Fathir 27-28, Q.S Al-An'am: 99) and etc (Abidin, 2017).

Picture 1. Students observed the moon with new computerized telescope in $4^{\text {th }}$, October 2019 (Trensains Sragen)
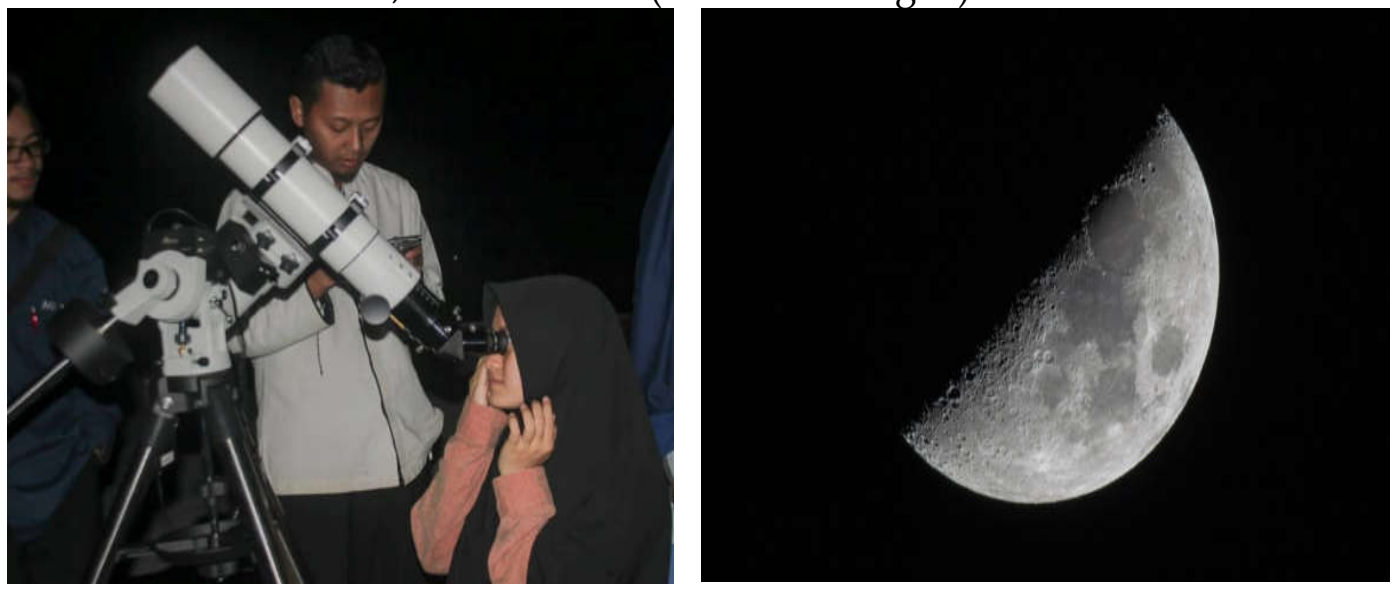

Source: reported on Sunday, October 13, 2019 at $01.50 \mathrm{pm}$

Picture 1 shows that students in SMA Trensains Muhammadiyah, Sragen observed the moon with the new computerized telescope. This telescope can be set up so that it can be observed out space objects clearly. Through the observation program, student not only learned about theoretical things in Quran but also directly implemented the qauniyah verses. Students got more impressed and attractive than before, other than that with the new telescope provided (reported on Sunday, October 13, 2019 at $01.50 \mathrm{PM}$ ). 
2. Weekend-midnight program

Midnight program or Tahajud Fisika is the specific program that implemented Qur'an Science in real life. This term means weekend activity for students in learned physic from Saturday morning until Sunday before Subuh prayer. Students started the learning process at 07.00 AM-12.00 PM on Saturday, after that students took lunch break. The learning began again at 20.00-21.00 PM, and took a break for a while. Then, at 22.30-00.30 midnight program started for the next session until 01.00-03.00 AM for Tahajud and Subuh prayer. Trensains cooperate with ITS (Insititut Teknologi Surabaya) lecturer and post-graduate student as a mentor. Meanwhile, the main theme of this program consistent in natural science, in this program the theme is calculus (Azalia Mutammimatul Khusna, 2018).

Picture 2. Students in Trensains Sragen on midnight program (Tahajud Fisika) in $10^{\text {th }}$, November 2018

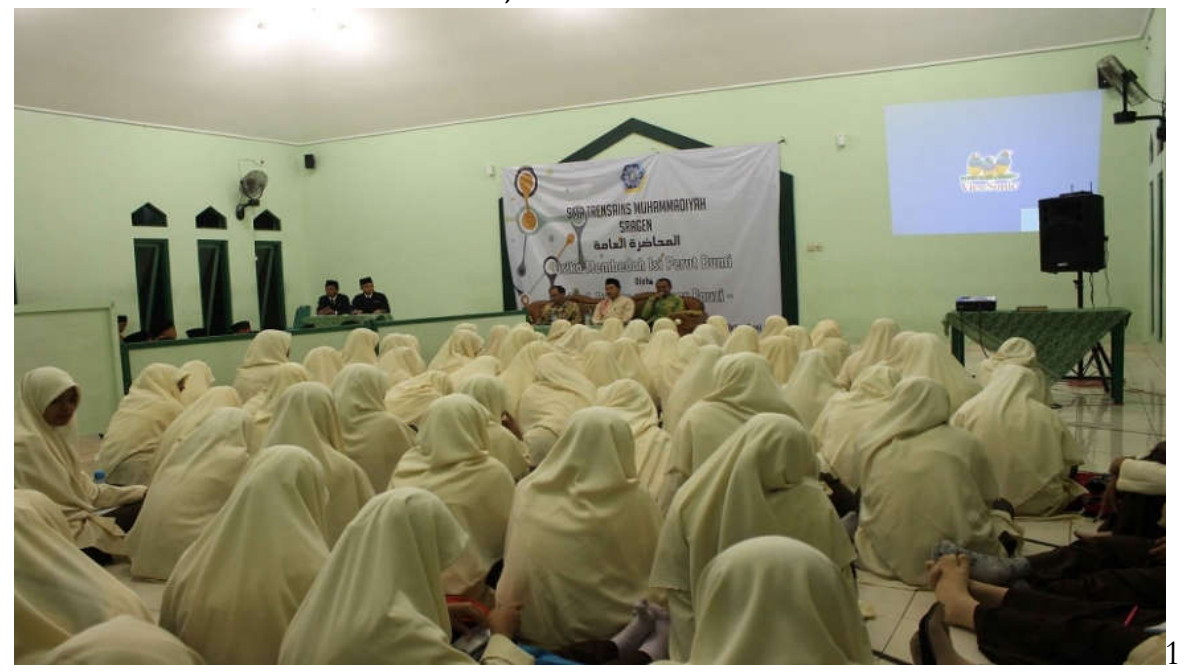

Source: reported by gomuslim.co.id on November 10, 2018

Picture 2 shows that students in SMA Trensains Muhammadiyah, Sragen in midnight program (Tahajud Fisika) like what reported by gomuslim.co.id on November 10, 2018. Tahajud Fisika is a unique program as the identity of Trensains. The discussion about physic as the closest science to God based on natural science and continued with tahajud and subuh prayer

\section{Studium generale}

The studium generale in Trensains is a routine activity with diversity experts, especially in natural science. This program usually started at 08.00 PM until midnight and discussed the phenomenon of universe based on Quran and Hadith as primary sources. This program is scheduled at least once a month with intended for students, teachers, also for the public. At the end of studium generale, continued by photo session, personal discussion, etc. Studium generale also aims for interesting and understanding from students (reported on Sunday, September 22, 2019 at 11.00 AM). This activity aims to upgrade the basic natural science and contemporary issues for students in Trensains. 
Picture 3. Studium generale in Trensains Sragen by Prof. Dr. Satria Bijakasana with the theme about Earth's Magnetic Field in 11 th , April 2019

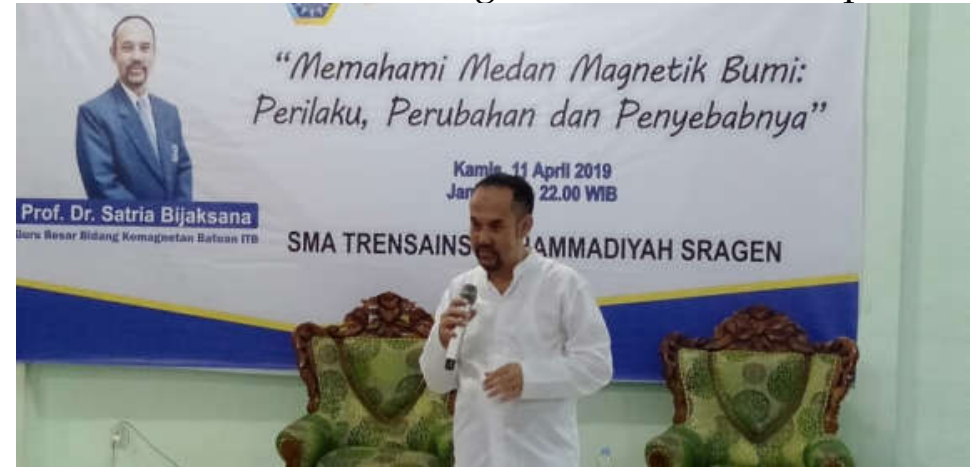

Source: reported by trensains.sch.id on April 11, 2019

Picture 3 shows that students in SMA Trensains Muhammadiyah, Sragen has held studium generale. Satria Bijaksana as the key speaker described the magnetic field in Earth. Many studium generale has been held in Trensains with many key speaker on their capability and capacity. Most of the themes in natural science based on Quran and Hadith. This event got more enthusiasm from students because started after Isha prayer until midnight. The students have given freedom to asked many questions too, so they could be more excited and known every particular thing like what (reported by trensains.sch.id on April 11, 2019).

\section{CONCLUSION}

Based on discussion, the systemization of Islamic schools commonly still metaphysically and pragmatically area. So, Islamic Education in this 4.0 Era should be transformed from classical method and theological aspect into modernity human life. As the problem-solver, unlikely the general schools that still applies normative regulations and tends to be stagnant. Trensains has made variety of changes with their own curriculum and national curriculum to unified and classified Islamic education into formal education. The unification curriculum implemented with primary subject as national curriculum regulation, while the support subjects are the differentiator from Trensains with other schools. This support system divided as well to each program and focused on natural science that had differences from other schools whos still focused on social science. Initiated by Agus Purwanto, the support programs not only combine qauniyah verses in Quran, but also learning to find out the science from Quran with experts that invited by SMA Trensains Muhammadiyah, Sragen.

Unfortunately, not all of Islamic school can implemented programs as well as Trensains because of human sources and networking link. As the analysis of research data in introduction before, the changes to progressivity and revolutionary era of Islamic curriculum reflected with Trensains will be following these steps. First, the Islamic curriculum as the core of education and religion itself, adaptive and adoptive with technologies media. This integrated activity increase student enthusiasm with higher score than before can be produced by. Second, as one of the independently Islamic Education, SMA Trensains Muhammadiyah in Sragen would it be a role model for others in learning processed and implemented of media-based for qauniyah verses in Quran based on collaboration concepts. Third, Islamic education in general activity has to 
expand the link between one and another institution to collaborate and cooperate. For example, Trensains initiated several schools as guidance in the implementation of Quran and Hadith based on natural science. Finally, the Islamic curriculum as part of the national curriculum should be more progression to the next level through the development in the implementation of Quran and Hadith. Ideally, Islamic school analyzes the primary sources with learning media and technology to emphasized students both inside between knowledge and practice, in spiritual (theological, pragmatical, and ritual) and intellectual (natural science and social science). Due to the implementation of qauniyah verses in Quran with several programs based on emphasized of natural science, students more attracted and interested in learning process. While using technology and media, Islamic education not longer in the pragmatical area but more practical and empirical in religious activity.

\section{REFERENCE}

Abidin, Z. (2017). Integrasi Islam dengan Fisika dan Kimia. Al-Afkar, 5(2).

Ajahari. (2016). Pemikiran Fazlur Rahman dan Muhammad Arkoun A. Jurnal Studi Agama Dan Masyarakat, 12(2), 232-262.

Azalia Mutammimatul Khusna, A. I. S. (2018). Pembelajaran Integratif Sains dan AlQur'an: Revitalisasi Nilai Ajaran Islam dan Pembentukan Karakter di SMA Trensains Sragen. Iqra' Jurnal Kajian Ilmu Pendidikan, 3(1), 56-84.

Crabtree, S. (2010). Religiosity Highest in World's Poorest Nations. Washington, D.C: Gallup Global Financial Health Study.

Hackett, C. (2012). The Global Religious Landscape: A Report on the Size and Distribution of the World's Major Religious Groups as of 2010. (August 2014). https:// doi.org/10.13140/2.1.4573.8884

Harahap, A. (2018). Integrasi Alquran dan Materi Pembelajaran Kurikulum Sains pada Tingkat Sekolah di Indonesia: Langkah Menuju Kurikulum Sains Berbasis Alquran. Jurnal Penelitan Medan Agama, 9(1), 21-46.

Hasanah, S. M. (2018). Brand Image Building in Islamic Higher Education. Proceeding International Conference of Islamic Education, 3, 61-68.

Hermawan. (2017). Interaksi Islam dan Sains: Studi Historis-Fenomenologis di SMA Trensains Sragen. Cakrawala: Jurnal Studi Islam, 12(2), 101-112.

Khoirudin, A. (2017). Sains Islam Berbasis Nalar Ayat-ayat Semesta. At-Ta'dib, 12(1).

Kurroti A'yun, Wildanul Fajri, S. (2018). Aktualisasi Kurikulum Terintegrasi di SMA Trensains Tebuireng Jombang. Al-Idaroh, 2(2), 24-49.

Maksudin. (2018). Integration of School and Pesantren Educational System A Model of Character Education: Perspective of Educational Transformation. International Journal on Islamic Educational Research (SKIJIER), 1(2018), 32-59.

Miles, M. B., Huberman, A. M., \& Saldaña, J. (2014). Qualitative Data Analysis. Los Angeles: Sage.

Mohamad Yasin Yusuf, Sutrisno, K. (2017). Epistomologi Sains Islam Perspektif Agus Purwanto. Analisis, 17(3), 65-90.

Munadi, M. (2016). Integration of Islam and Science: Study of Two Science Pesantrens (Trensain ) in Jombang and Sragen. 5(December).

Muslih. (2018). Pembelajaran Ayat-ayat Kawniyah di SMA Trensains 2 Pesantren Tebuireng Jombang. Islamica, 12(2), 455-480.

Vol. 4 No. 2, Desember 2019

J-MPI homepage: http://ejournal.uin-malang.ac.id/index.php/jmpi/index 
Mustakim, M. (2017). Transformasi Pesantren Sebagai Pusat Penyebaran Islam, Alat Revolusi dan Lembaga Pendidikan Islam. At-Tajdid: Jurnal Ilmu Tarbiyah, 6(2).

Muttaqin, A. (2018). Konstruksi Kurikulum Sains Islam Keindonesiaan (Integrasi Islam, Sains Kealaman, Sains Humaniora dan Keindonesiaan). 16(1), 80-96.

Nurmadiah. (2014). Kurikulum Pendidikan Agama Islam. Al-Afkar, 3(2).

Pew Research Center. (2012). The Global Religious Landscape. Washington, D.C: Pew Research Center's Forum.

Priatmoko, S. (2018). Memperkuat Eksistensi Pendidikan Islam di Era 4.0. Ta'lim: Jurnal Studi Pendidikan Islam, 1(2), 221-239.

Kementerian Agama RI. (2019). Rencana Strategis Direktorat Jenderal Pendidikan Islam.

Silahudin. (2014). Kurikulum dalam Perspektif Pendidikan Islam (Antara Harapan dan Kenyataan). Mudarrisuna, 4(2), 331-355.

Stoet, G., \& Geary, D. C. (2017). Students in countries with higher levels of religiosity perform lower in science and mathematics. Intelligence, 62, 71-78. https:/ / doi.org/10.1016/j.intell.2017.03.001

$\mathrm{Su}, \mathrm{S}$. (2012). The Various Concepts of Curriculum and the Factors Involved in Curriculamaking. Languange of Teaching and Research, 3(1). https://doi.org/10.4304/jltr.3.1.153-158

Yusuf, M. Y. (2015). Pesantren Sains: Epistemology of Islamic Science in Teaching System. Walisongo, 23(2), 283-310. 